\title{
«Ubehagets pedagogikk» - en inngang til kritisk refleksjon og inkluderende undervisning? ${ }^{1}$
}

\author{
Ase Røthing \\ Seksjon for mangfoldsstudier \\ Institutt for internasjonale studier og tolkeutdanning \\ OsloMet - Storbyuniversitetet \\ aserot@oslomet.no
}

\section{Keywords:}

pedagogy of discomfort

diversity

anti-oppressive and inclusive education.

\footnotetext{
1 Jeg vil gjerne takke gode kollegaer ved IST (Institutt for internasjonale studier og tolkeutdanning), for samtaler som over tid har vært med på å forme noen av tankene i denne artikkelen. En særlig takk til Jo Helle-Valle og Thorgeir Kolshus.
} 
Abstract

"Pedagogy of discomfort" was first introduced by Boler in 1999 as a teaching practice that invites educators and students to engage in critical inquiry regarding values and norms, and to examine constructed self-images and perceptions of others (1999, $p$. 177). The concept has later been further developed by Boler and Zembylas (2003) as a pedagogical framework to engage students and teachers with issues of difference, race and social justice by challenging their emotional comfort zones. This pedagogical approach is grounded in the assumption that discomforting emotions are important in challenging dominant beliefs, social habits and normative practices that sustain stereotypes and social injustice and in creating openings for empathy and transformation. (Zembylas \& Papamichael, 2017, p. 3). This article explores how pedagogy of discomfort may contribute to critical reflections and inclusive education, by asking what educators may gain from dwelling with discomfort rather than trying to escape it. I argue that discomfort may function as an approach to critical reflections and new knowledge, and a resource for transformation, not as something to fear and avoid. However, the ideas of pedagogy of discomfort have raised concerns for what might happen when students are challenged and become uncomfortable in educational settings. One might argue that the concept of "classroom safety" could imply that educators first and foremost should offer comfort in classrooms. My main interest in this article is what educators may gain from engaging with discomfort as a resource for critical reflections and inclusive education. 


\section{Innledning}

Utdanning innebærer alltid en risiko fordi «utdanning ikke er et teknisk maskineri, men et møte mellom mennesker» (Biesta 2014, s. 23). I risikoen ligger blant annet muligheten for det uforutsette, det uhåndterbare og det ubehagelig. Undervisning som ikke bekrefter og reproduserer elevenes vante forestillinger og som utfordrer maktforhold, kan skape engasjement og nysgjerrighet men også aggresjon og kriser for elever (jf. Kumashiro 2002). Undervisere som tar sjansen på å problematisere etablerte forståelsesmåter, risikerer å skape ubehag for elever, studenter og seg selv.

Nyere norsk forskning basert på klasseromsobservasjoner og intervjuer med lærere, indikerer at lærere kan kjenne på ubehag og rådvillhet når elever ytrer seg negativt eller hatefullt overfor grupper av mennesker, enten dette er knyttet til rasisme (Svendsen 2014), innvandring (Eriksen 2013), antisemittisme (Thomas 2016; Often 2017), homoseksualitet (Røthing 2007) eller høyreekstremisme og fremmedfiendtlighet (Røthing 2017). Anker og von der Lippe $(2015,2016)$ har unders $ø$ kt skolers behandling av hendelsene 22 . juli, og antyder at skolene i begrenset grad har brukt 22. juli som utgangspunkt for kritiske drøftinger av udemokratiske holdninger. De forstår dette i lys av at lærere ikke har tilstrekkelig kompetanse til å undervise om kontroversielle og sensitive temaer, og at det å «åpne for debatter som kan ta ukontrollerbare retninger, kan oppleves utrygt» (2015, s. 94). Langs samme linje argumenterer Iversen (2012), basert på klasseromsobservasjoner av RLE-undervisning på ungdomstrinnet, for at lærere ofte søker å skape et «enighetsfellesskap» i klassen når de underviser om temaer som elevene har ulike meninger om. Gjennom å framsnakke områder elevene kan enes om, framfor å utforske uenighetene, søker de å unngå konfrontasjoner, uhåndterbare situasjoner og ubehag.

Ubehag er nettopp ubehagelig og noe de fleste intuitivt vil søke seg bort fra. Med ubehag sikter jeg i denne artikkelen til et bredt spekter av følelser og erfaringer som frustrasjon, usikkerhet, oppgitthet og bekymring. For noen år siden gjorde jeg klasseromsobservasjoner på en ungdomsskole sammen med to kollegaer, i forbindelse med et forskningsprosjekt om «forståelser av norskhet» i skolen. Mange av skoletimene som vi observerte var preget av kaos og høyt støynivå. Vi kjente på et sterkt ubehag knyttet til å være tilstede og se frustrerte, fortvilte lærere som ga tydelig uttrykk for at de følte at de mislyktes. Samtidig kjente vi på stort ubehag ved å observere frustrerte, resignerte, tause og vrange elever som vi både fikk sympati med og ble irritert over. Ubehaget var utmattende og vi orket knapt å gjennomføre fulle skoledager med observasjoner. Noen måneder senere gjorde jeg observasjoner på en annen skole, hvor det var en helt annen atmosfære. Noe av det jeg husker best fra denne skolen var min egen enorme lettelse over å se elever og lærere i konstruktivt samspill og å slippe unna det utmattende ubehaget. I et nyere forskningsprosjekt om mangfold i yrkesfag har jeg fornemmet en lignende opplevelse blant lærere jeg intervjuet. Flere av dem ga uttrykk for et ubehag knyttet til å snakke om forskjeller blant elevene, og mer konkret å snakke om utfordringer knyttet til elever med etnisk eller religiøs minoritetsbakgrunn (Røthing 2017. Jf. også Zembylas 2010). Men kanskje like slående som ubehaget, var det jeg oppfattet som stor lettelse blant de som ble intervjuet, når de kunne snakke positivt om minoritetselever og elevforskjeller, blant annet knyttet til minoritetselever som ressurser i undervisningen. På den måten slapp lærerne, slik jeg oppfattet det, bort fra ubehaget.

De senere årene har det vokst fram internasjonal forskning som fokuserer på hvordan ubehag kan behandles og forstås som en ressurs innen utdanningsfeltet. «Pedagogy of discomfort» (Boler 1999; Boler \& Zembylas 2003) er utviklet og anvendt i forsøk på å engasjere elever, lærerstudenter og lærere i arbeid med forskjeller og maktforhold (se f.eks. De Freitas \& McAuley 2008; Cutri \& Whiting, 2015; Zembylas 2010; Zembylas \& Papamichael 2017). Perspektivene springer ut fra ulike antidiskriminerende og antirasistiske tradisjoner som vektlegger arbeid for «social justice» i brei forstand. I første del av denne artikkelen vil jeg innledningsvis presentere «ubehagets pedagogikk». Deretter vil jeg presentere noen andre pedagogiske perspektiver som springer ut fra beslektede teoretiske landskap og som har mer 
eller mindre sammenfallende ambisjoner, og se disse perspektivene i sammenheng. I andre del av artikkelen vil jeg drøfte noen empiriske eksempler for å undersøke om ubehag kan være en ressurs og en inngang til kritisk refleksjon og inkluderende undervisning. Eksemplene er hentet fra to ulike empiriske studier. Det ene prosjektet handlet om norskhet i skolen og innebar både klasseromsobservasjoner, intervjuer med lærere og analyser av læreplaner og lærebøker. ${ }^{2}$ Det andre prosjektet satte søkelys på hvordan elever og lærere ved fire yrkesfaglige studieprogram, opplevde undervisning knyttet til mangfold i brei forstand. Dette var et samarbeid med kollega Hedvig Skonhoft Johannesen og vi gjorde intervjuer ved 10 ulike skoler med beliggenhet over hele landet. ${ }^{3}$ Sitater og eksempler fra disse to studiene brukes som utgangspunkt for å drøfte noen konkrete fenomener og skal ikke leses som forsøk på en helhetlig presentasjon av et større empirisk materiale.

Min første interesse for ubehaget var knyttet til det jeg oppfattet som en stor lettelse blant lærere over å kunne slippe bort fra ubehaget. Det var med andre ord ikke knyttet til ubehaget i seg selv, men til hva ønsket om å unnslippe det kunne føre til. Med utgangspunkt i perspektiver som setter søkelys på makt i utdanningsfeltet, ble det tydelig at det å rømme unna ubehag framfor å anvende det som en ressurs, kan få problematiske følger. Underveis $i$ arbeidet med denne artikkelen ble det imidlertid stadig klarere for meg at det finnes ubehag i utdanningsfeltet som ikke uten videre kan forstås og behandles innenfor rammene av en type maktkritiske perspektiver der det på forhånd ligger klare føringer for hvordan makt er satt i spill og hvem som kan forstås som utsatte eller sårbare. I siste del av artikkelen setter jeg søkelys på dette ved å drøfte eksempler på det jeg har valgt å kalle upassende ubehag. I denne artikkelen vil jeg derfor argumentere for at ubehag kan være en ressurs og en inngang til å videreutvikle maktbevissthet og inkludering i tråd med etablert antidiskriminerende pedagogikk. På den andre siden vil jeg argumentere for at ubehag som oppleves upassende også kan være en ressurs $\mathrm{i}$ arbeidet for kritiske refleksjon og økt innsikt $\mathrm{i}$ egne forståelsesmåter, og at det derfor er nødvendig å ta på alvor ubehag som ikke fanges opp av etablerte maktkritiske perspektiver.

\footnotetext{
2 Studien pågikk i perioden 2007-2010 og var tilknyttet og finansiert av forskningsprogrammet Kulturell kompleksitet $i$ det nye Norge (CULCOM) ved Universitetet i Oslo. Jeg gjorde observasjoner på to skoler i Oslo med ulik elevsammensetning både med hensyn til etnisitet og sosioøkonomisk bakgrunn. Den ene skole lå på østkanten og her hadde omkring $75 \%$ av elevene etnisk minoritetsbakgrunn, den andre skolen lå i sentrum/vest og her hadde omkring $70 \%$ av elevene etnisk norsk bakgrunn. Observasjonene varte i 6 uker på begge skoler og ble gjort på 8. trinn på den ene skolen og 9. trinn på den andre. Jeg observerte først og fremst undervisning i samfunnsfag og Religion, livssyn og etikk (RLE), og jeg var inne i alle klasser på trinnet. I tillegg gjorde jeg observasjoner i tre dager på 8 . trinn på en skole i en småby på Vestlandet. Til sammen 14 lærere fra de tre skolene, syv kvinner og syv menn, ble intervjuet. På den ene skolen gjorde jeg observasjoner sammen med Arnfinn H. Midtbøen, som var vitenskapelig assistent for prosjektet i noen måneder, og sammen med Stine H. B. Svendsen som gjorde observasjoner $\mathrm{i}$ forbindelse med sitt doktorgradsprosjekt (se Svendsen 2014). Midtbøen gjennomførte også noen av intervjuene med lærere ved den første skolen. For mer informasjon om prosjektet og det empiriske materialet, se Røthing 2011.

3 Vi intervjuet elever og lærere i separate grupper på 3-5 personer. De var knyttet til følgende fire yrkesfaglige utdanningsprogram: Bygg- og anleggsfag, Elektrofag, Helse- og oppvekstfag og Restaurant- og matfag. Intervjuene fokuserte på behandling av temaer som urfolk, nasjonale minoriteter, innvandring, rasisme og radikalisering. Intervjuene ble gjort i perioden april-september 2015. To av skolene ligger på mindre tettsteder mens de øvrige ligger $i$ en by. Vi gjennomførte til sammen 23 intervjuer hvorav 10 er med elever og 13 med lærere. Åtte av lærerne underviste i samfunnsfag fellesfag, de øvrige i programfag. De aller fleste elevene som ble intervjuet gikk 2 . år i videregående skole. Johannesen gjennomførte syv intervjuer mens jeg gjennomførte de øvrige 16 . Intervjuene med elevene varte vanligvis omkring 45 minutter, mens intervjuene med lærerne vanligvis varte noe lengre, ofte i overkant av en time. Alle intervjuene ble gjort på skolene og i skoletiden, de ble tatt opp på bånd og transkribert $\mathrm{i}$ sin helhet. I denne artikkelen er det intervjuene med lærerne som er i fokus. For en mer utfyllende beskrivelse av datamaterialet og for en bredere diskusjon av deler av materialet, se boka Mangfoldskompetanse. Perspektiver pa undervisning $i$ yrkesfag (Røthing 2017).
} 


\section{Ubehagets pedagogikk}

Begrepet «pedagogy of discomfort» ble først introdusert av Boler i 1999, som beskrev det som en undervisningspraksis som «starter med å invitere lærere og studenter til å involvere seg i kritiske undersøkelser av verdier og etablerte oppfatninger, og å undersøke konstruerte selvforståelser i relasjon til hvordan man har lært å forstå andre» (s. 177, min oversettelse), og er senere videreutviklet av Boler \& Zembylas (2003). Ubehagets pedagogikk ble utviklet som et pedagogisk rammeverk som søker à engasjere elever, studenter og lærere til å behandle temaer knyttet til forskjeller, sosial rettferdighet og rasisme, på måter som utfordrer deres «emosjonelle komfortsoner». Utgangspunktet var en antakelse om at «ubehagelige følelser» er viktige i arbeidet med «å utfordre etablerte oppfatninger, sosiale vaner og normative praksiser, som opprettholder stereotypier og sosial urettferdighet, ved å skape åpninger for empati og forandring» (Zembylas \& Papamichael 2017, s. 3, min oversettelse). Målet er, skriver Zembylas \& Papamichael (2017), som blant annet drøfter hvordan ubehagets pedagogikk kan anvendes i flerkulturell lærerutdanning, «å avdekke og stille spørsmål ved dypt integrerte emosjonelle dimensjoner som rammer inn og former daglige vaner, rutiner og ubevisst medvirkning til å opprettholde maktforhold» (s. 3, min oversettelse). En helt sentral tanke er at ubehag kan forstås som en ressurs, og at det kan være viktig i antirasistisk og antidiskriminerende undervisning å motstå fristelsen til å unngå ambivalens og ubehag. Boler \& Zembylas (2003) hevder at «tvetydighet er skremmende og en kilde til ubehag for de som er tvunget til å leve i en kultur definert av enkle binære motsetninger» (s. 122). De Freitas \& McAuley (2008), som med utgangspunkt i blant annet ubehagets pedagogikk, drøfter innganger til à synliggjøre og bearbeide hvithet som privilegium blant hvite lærerstudenter, følger denne tankegangen når de argumenterer for at «målet med identitetsutvikling bør ikke være å overskride ubehag, men heller å omfavne ubehag som en del av det pågående følelsesmessige arbeidet med å konfrontere ens egne privilegier» (2008, s. 433 , min oversettelse).

Ubehagets pedagogikk springer ut fra ulike antidiskriminerende og antirasistiske tradisjoner som vektlegger arbeid for sosial rettferdighet. Felles for denne typen pedagogiske tilnærminger er at de i større eller mindre grad trekker veksler på postkoloniale, skeive, feministiske og interseksjonelle perspektiver, kritisk raseteori, kritiske hvithetsstudier, samt det som blant annet May (2009) beskriver som kritisk flerkulturell pedagogikk. Alle disse perspektivene kan sies å invitere til kritiske undersøkelser av prosesser som skaper og opprettholder privilegier og maktforhold i ulike kontekster, knyttet til for eksempel religion, hudfarge, kultur, funksjonalitet, sosial klasse, kjønn eller seksualitet (Mühleisen, Røthing \& Svendsen, 2009, s. 17). En sentral ambisjon innen ubehagets pedagogikk er, i tråd med denne typen perspektiver, å problematisere hvordan elever lærer å forstå seg selv og andre. I boka Troubling Education beskriver Kumashiro (2002) fire ulike typer antidiskriminerende undervisning og to av dem fokuserer nettopp på undervisning henholdsvis for «den andre» og om «den andre». Begge disse tilnærmingene har noen åpenbare styrker, ved at de bidrar til å gjøre undervisere bevisst på elevmangfold og på skolenes ansvar for å ivareta og legge til rette for dette mangfoldet. Undervisning om de andre kan dessuten være et forsøk på à «normalisere forskjeller og annerledeshet ved å oppmuntre studenter til å se og behandle andre måter å være på, som akkurat like 'normalt' og akseptabelt som normative måter å være på» (Kumashiro 2002, s. 41-42, min oversettelse). Kumashiro påpeker imidlertid at begge disse tilnærmingene har signifikante svakheter ettersom de legger til grunn at undervisere må definere «de andre». Denne prosessen kan føre til at «annerledeshet kan bli essensialisert og forbli forskjellig fra normen» (s. 41-42). Undervisning om de andre bidrar dessuten ofte til å posisjonere «den andre» som «ekspert» eller «representant» på måter som kan bidra til å befeste forestillinger om «den sosiale, kulturelle og til og med intellektuelle avstanden og forskjellen mellom normen og 'den andre'» (s. 41-42). De to siste av de fire formene for antidiskriminerende undervisning som Kumashiro identifiserer, beskrives som bedre egnet enn de to første til å skape inkludering og sosial rettferdighet. Disse to omtaler 
han som «Utdanning som er kritisk overfor privilegering og andregjøring» (2002, s. 44-50) og «Utdanning som endrer studenter og samfunn» (s. 50-70).

Ubehagets pedagogikk kritiserer undervisning som reproduserer stereotypier om «de andre» - og underforstått også om «oss» - og som ikke behandler og utfordrer maktforhold. Ubehagets pedagogikk plasserer seg derfor tydelig som varianter av type 3 og 4 i Kumashiros kategorisering av ulike antidiskriminerende undervisningspraksiser. Et sentralt tema i litteraturen som på ulike måter utforsker ubehag, er kritikk av såkalt «velvillig» flerkulturell pedagogikk (jf. May 2009). Dette er tilnærminger som anklages for essensialisering og for å komme til kort når det gjelder å behandle rasisme og sosial urettferdighet, fordi de nøyer seg med et overfladisk fokus på forskjeller med vekt på mat, klær og musikk (f.eks. Zembylas \& Papamichael 2017, s. 9). Andre deler av litteraturen er særlig opptatt av å behandle ubehag knyttet til rasisme og hvithet (f.eks. De Freitas \& McAuley 2008), og i dette ligger også en kritikk av den tidlige flerkulturelle pedagogikken som anklages for å fokusere ensidig på kultur og kulturforskjeller, og for å bidra til å etablere en «de-rasialisert diskurs» (May 2009, s. 35). Det har riktignok blitt argumentert for at det er «sentralt i kritisk multikulturalisme à navngi og aktivt utfordre rasisme og andre former for urettferdighet, ikke bare å gjenkjenne og feire forskjeller og redusere fordommer» (Berlak og Moyenda 2001, sitert i May 2009, s. 35, min oversettelse), men det er like fullt en gjentakende kritikk at disse ambisjonene ikke følges opp.

Fokuset på ubehag kan indikere at ubehagets pedagogikk er tett forbundet med det som gjerne kalles den «affektive vendingen». Ifølge Clough (2007) viser dette til at «i en tid da kritisk teori sto overfor analytiske utfordringer knyttet til krig, traumer, tortur, massakre og terrorisme» (s. 2), oppsto en vending i retning av affekt. Det er opplagt ulike vektlegginger innen dette teoretiske landskapet, men den affektive vendingen innebærer gjennomgående «en vesentlig vending mot samspillet [intersections] mellom det sosiale, kulturelle og politiske, og det psykiske og ubevisste» (Zembylas 2014, s. 397). Med unntak av noen av publikasjonene til Zembylas (se 2010, 2014 og 2015), en sentral bidragsyter innen litteraturen om ubehagets pedagogikk, er det imidlertid lite eksplisitt fokus på affekt eller affektiv teori i litteraturen om ubehagets pedagogikk som jeg har jobbet med. «Discomfort» ser tvert imot ut til å referere til et bredt spekter av beslektede følelser og erfaringer som frustrasjon, rådvillhet, irritasjon og bekymring. Denne brede anvendelsen er i tråd med min bruk av begrepet i denne artikkelen.

I forlengelsen av utviklingen av begrepet «pedagogy of discomfort» har det, ikke overraskende, vokst fram litteratur som drøfter etiske implikasjoner. Det har blitt argumentert for at noe ubehag ikke bare er uunngåelig når man arbeider med sosial rettferdighet og tar opp temaer som rase og rasisme i undervisning, men at det også er nødvendig dersom man ønsker å skape endring (Berlak 2004, sitert i Zembylas 2015; Zembylas \& Papamichael, 2017). Det er nettopp provokasjon, det å fremkalle en reaksjon, som åpner opp for å skape forandring. Allerede i 1992 argumenterte Felman, med henvisning til sin erfaring med å undervise om Holocaust, for følgende:

If teaching does not hit upon some sort of crisis, if it does not encounter either the vulnerability or the explosiveness of a (explicit or implicit) critical and unpredictable dimension, it has perhaps not truly taught... I therefore think that my job as a teacher, paradoxical as it may sound, was that of creating in the class the highest state of crisis that it could withstand, without "driving the students crazy", without compromising the students' bounds (s. 53, kursiv i original. Sitert i Zembylas 2015, s. 164).

I Troubling Education (2002) viser Kumashiro til nettopp Felman (1992) og argumenterer for at det er både «pedagogisk og etisk passende [appropriate] å framkalle ubehagelige følelser hos studentene, så lenge skadene [harm] som er gjort blir behandlet forsvarlig» (s. 79). I tråd med dette utfordrer Zembylas (2015) ideen om at konseptet «classroom safety» skal innebære at utdannere først og fremst skal tilby behagelige klasserom. Han argumenterer for 
at «trygghet» ikke bør bli forstått som «fravær av ubehag»og at «å erfare ubehag må ikke bli sammenblandet med fravær av trygghet» (Zembylas 2015, s. 165). I litteraturen som springer ut fra begrepet ubehagets pedagogikk er det med andre ord en utbredt enighet om at ubehag er både uunngåelig og nødvendig $i$ arbeidet med å skape forandring. Samtidig er det stort fokus på at ubehagets pedagogikk bør praktiseres i kombinasjon med pedagogiske perspektiver som i ulike varianter fokuserer på sårbarhet, empati, toleranse, håp og etiske utfordringer (f.eks. Cutri \& Whiting 2015; Zembylas 2010, 2015; Zembylas \& Papamichael 2017).

\section{Normkritisk pedagogikk og "hot moments"}

I skandinavisk kontekst kjenner vi perspektivene og ambisjonen som kommer til uttrykk innen ubehagets pedagogikk, fra litt ulike varianter av kritisk flerkulturell pedagogikk (f.eks. Skinstad van der Kooij 2014; Westrheim 2014), men ikke minst fra det som gjerne omtales som normkritisk pedagogikk (Bromseth \& Darj (red.) 2010; Kalonaityté 2014; Martinsson, Reimers, Reingarde \& Lundgren 2007; Martinsson \& Reimers (red.) 2008; Røthing \& Svendsen 2009; Røthing, 2016). Den normkritiske pedagogikken vokste fram i Sverige i stor grad som en direkte kritikk av det som gjerne blir omtalt som «toleransepedagogikk». Toleransepedagogikken refererer til ulike varianter av undervisning for og om «de andre» (jf. Kumashiro 2002), som for eksempel tilnærminger som legger vekt på kunnskap om kulturuttrykk heller enn å fremme kritiske refleksjoner omkring maktforhold og urettferdighet. En parallell finner vi i det som i USA kalles «Disability Awareness Day», som har til hensikt å skape økt aksept for mennesker med funksjonsnedsettelser gjennom at elevene for eksempel får prøve å «være» blind eller sitte i rullestol. Denne typen tilnærminger kritiseres for å tvert imot reprodusere negative stereotypier og få elevene til å synes synd på folk med funksjonsnedsettelser framfor å få økt innsikt i diskriminering og samfunnets normer knyttet til funksjonalitet (Lalvandi \& Broderick 2013).

Den normkritiske pedagogikkens overgripende ambisjon er «å skape varig bevissthet om samfunnsmessige maktrelasjoner som det går å overføre til situasjoner utenfor klasserommet», skriver Kalonaityte i boken Normkritisk pedagogik för den högre utbildningen (2014, s. 8, min oversettelse). Her peker hun etter mitt syn på to helt sentrale poenger ved en normkritisk tilnærming i utdanningsfeltet. For det første er det et mål at den maktkritiske bevisstheten som elever og studenter utvikler skal være varig, som en slags ryggmargsrefleks. For det andre er det avgjørende at den normkritiske kompetansen kan anvendes på ulike arenaer, ikke bare i skolekonteksten. I boka Seksualitet i skolen. Perspektiver på undervisning (Røthing \& Svendsen 2009) la vi vekt på samme typen ambisjoner. Vi valgte imidlertid å bruke Kumashiros begrep antidiskriminerende undervisning framfor normkritisk pedagogikk, blant annet fordi vi mente norm-begrepet var for smalt i forhold til variasjonen av de problemstillingene vi var opptatt av. Vi formulerte «undervisning som problematiserer privilegier for å skape endring», som en variant av Kumashiros type 3 og 4, som vårt mål (Røthing \& Svendsen 2009, s. 65-70). Vi argumenterte dessuten for at når undervisningen utfordrer og problematiserer elevenes etablerte kunnskap kan læring også innebære avlæring, og at dette, slik også Kumashiro (2002) har påpekt, kan skape ulike former for «kriser» for elevene (Røthing \& Svendsen 2009, s. 71).

Litteraturen som behandler ubehag fokuserer mye på etnisk og kulturell forskjellighet, mens normkritisk pedagogikk i stor grad behandler temaer knyttet til kjønn og seksualitet. De deler imidlertid en teoretisk innretning med tydelig interseksjonell profil, der ulike differensieringsprinsipper, som både kjønn, sosial klasse, funksjonalitet, etnisitet, hudfarge, alder, seksualitet og religion, framheves og ses i sammenheng i pedagogisk arbeid. Selv har jeg argumentert for at mangfoldsbegrepet kan være en nyttig inngang til denne typen pedagogisk arbeid og refleksjon, og at lærere og lærerutdannere trenger kritisk mangfoldskompetanse (Røthing 2016, 2017). Dette viser til en kombinasjon av relevant kunnskap, en interseksjonell tilnærming til mangfold, samt kjennskap til og anvendelse av 
maktkritiske perspektiver som for eksempel normkritisk pedagogikk. Tanken er at denne kombinasjonen er nødvendig for å kunne undervise på antirasistiske og inkluderende måter (se også May 2009, s. 44-45), og for å kunne bidra til den typen kritisk refleksjon som både normkritisk pedagogikk og ubehagets pedagogikk legger opp til.

Ubehagets pedagogikk setter fokus på og tar utgangspunkt i nettopp ubehag og ulike former for spenninger i utdanningsfeltet. Gressgård og Harlap (2014) drøfter spenninger i klasserommet og beskriver det, med henvisning til angloamerikansk pedagogisk litteratur, som «hot moments», forstått som «situasjoner der studentenes og/eller underviserens følelser når et nivå som truer med å forstyrre undervisning og læring, vanligvis utløst av en kommentar om et sensitivt tema» (s. 24). Denne typen kommentarer handler gjerne om det som kan kalles mikroaggresjon. I deler av litteraturen om mikroaggresjon er begrepet begrenset til markering av raseskiller, men Gressgård og Harlap bruker det mer generelt om «ytringer og handlinger som utpeker og knytter personer til stereotype oppfatninger om etnisitet, rase, kjønn, seksualitet eller andre etablerte sosiale skillelinjer» (2014, s. 24. Se også Sue (red.) 2010). Det sentrale ved dette begrepet er at det viser til ofte uintenderte og subtile handlinger som det kan være vanskelig å sette ord på, å ta opp og å kritisere, men som like fullt skaper ubehag og ydmykelse for den eller de som rammes, og som over tid kan utvikle seg til en stor belastning.

Begrepene «hot moments» og mikroaggresjon kan ses i sammenheng med ubehagets pedagogikk. I Gressgård og Harlaps (2014) diskusjoner av spenninger i klasserommet og mikroaggresjon som pedagogisk utfordring, drøfter de to case som begge viser til ulike former for ubehag. De løfter fram aspekter ved spenningene og ubehaget som oppstår $i$ de to situasjonene og diskuterer hvordan de involverte aktørene forstår situasjonene ulikt og slik blant annet bidrar til å skape spenninger. Definisjonen av «hot moments» ser imidlertid ut til å legge til grunn at dette er situasjoner som «truer med å forstyrre undervisning og læring» og som følgelig ikke kan bidra til à skape læring, slik det framstilles innen ubehagets pedagogikk. Her trer det med andre ord fram en motsetning mellom «hot moments» forstått - litt satt på spissen - på den ene siden som problem og på den andre siden som mulighet. Et sentralt spørsmål her er imidlertid de etiske implikasjonene som allerede ble berørt under presentasjonen av ubehagets pedagogikk. Både lærere, lærerstudenter og elever er ulike og er posisjonert forskjellig i klasserommet og samfunnet. Spørsmålet om trygge og behagelig klasserom, og om det er forsvarlig à skape ubehag hos lærerstudenter eller elever, er med andre ord komplekst og gjelder særlig i forbindelse med temaer knyttet til forskjeller, sosial rettferdighet og rasisme. Denne tematikken vil jeg vende tilbake til avslutningsvis.

Som vist i det foregående, framhever normkritisk pedagogikk bevisstgjøring og refleksjon som inngang til endringsarbeid $\mathrm{i}$ skolen. Ubehagets pedagogikk på sin side vektlegger ubehaget som en ressurs som kan bidra til å sette i gang andre refleksjoner og få fram nye aspekter ved utfordringer knyttet til maktforhold, utsatthet og inkluderende. Litteraturen som behandler ubehag i utdanningskonteksten fokuserer riktignok i hovedsak på samme type tematikk som normkritisk pedagogikk, og springer ut fra samme teoretiske landskap. Et bredt fokus på ubehag kan imidlertid fange opp utfordringer som ikke uten videre kan forstås og behandles innenfor rammene av normkritisk pedagogikk. I arbeidet med kritisk refleksjon og inkludering i utdanningsfeltet, kan ubehag i brei forstand være en ressurs om åpner for nye tilnærminger og ny innsikt. 


\section{Ubehagelig ubehag og problematisk lettelse?}

Hvilke uheldige effekter kan det få å søke seg til lettelsen for å slippe bort fra ubehag? Mitt utgangspunkt er en antakelse om at ubehag kan være en inngang til kritisk refleksjon omkring egne forståelser og undervisningspraksiser, og at rask flukt fra ubehag gjør at man går glipp av disse anledningene til økt forståelse for komplekse situasjoner.

I prosjektet «Mangfold i yrkesfag» satte vi fokus på hvordan mangfold i brei forstand behandles i undervisning i yrkesfag. Et tema som viste seg å bli sentralt, var lærernes perspektiver på elever med etnisk, religiøs, kulturell og eventuelt språklig minoritetsbakgrunn. Lærerne beskrev disse elevene både som utfordringer og ressurser (Røthing 2017, s.65-80). For flere av lærerne var det et tydelig ubehag forbundet med a snakke om utfordringer knyttet til minoritetselever og jeg fikk inntrykk av at det var en tydelig lettelse for dem å kunne fokusere på det positive ved å ha minoritetselever i klassen. Det var som om de ville ut av situasjonen, at de ville bli ferdige med å snakke om det problematiske og ubehagelige. Resultatet ble det jeg vil kalle framsnakking av positiv annerledeshet og jeg vil drøfte noen eksempler på dette i fortsettelsen.

Flere av lærerne vi intervjuet var opptatt av at minoritetselever har nyttig kunnskap og nyttige erfaringer. En gruppe lærere i helse- og oppvekstfag fortalte for eksempel om hvordan elever med hindu-bakgrunn kunne lære klassekameratene (og lærerne) om hvordan personer med tilknytning til hinduismen skulle behandles ved dødsfall. Andre fortalte om minoritetselever som kunne forklare religiøse spiseforskrifter. En annen type nyttig kunnskap var knyttet til erfaringer fra andre kontekster enn den norske. En programfagslærer ved byggog anleggsfag understreket at han generelt liker mangfold blant elevene, både når det kommer til kjønn og bakgrunn, og at han prøver å bruke deres ulike erfaringer. I forbindelse med krigen i Syria fortalte for eksempel Khalid «om ting som har skjedd der han kommer fra i Afghanistan».

Minoritetselevers nyttige kunnskap og erfaringer framsnakkes med de aller beste intensjoner. Samtidig er det åpenbare utfordringer knyttet til denne typen praksiser og framstillinger. Når lærere anvender elever som undervisere kan de samtidig stå i fare for å fraskrive seg ansvar for undervisningen. Samtidig kan de ikke minst bidra til å forsterke ulike former for problematisk representasjons- og gruppetenkning. Når Khalid fra Afghanistan automatisk tilskrives kompetanse om krigen i Syria er det åpenbart godt ment, men det er samtidig veldig upresist. Det å bruke eller peke ut elever som representanter kan på den ene siden innebære synliggjøring og anerkjennelse. Men elever som pekes ut gis samtidig mulighet til å fremme egne perspektiver, på bekostning av andre som eventuelt tilhører samme gruppe men som har andre perspektiver. Videre kan det å pekes ut som representant for en gruppe innebære eksotifisering, andregjøring og essensialisering, og det kan oppleves som en byrde for den det gjelder (jf. Røthing 2017, 97-100). En annen side ved dette er hvordan «representasjon» kan komme til å avgjøre hva som undervises i klasser med lite kulturelt og religiøst mangfold blant elevene. Både elever og lærere som ble intervjuet i prosjektet «Mangfold i yrkesfag», ga uttrykk for at det var en sammenheng mellom representasjon og innhold i undervisningen. Et typisk eksempel på dette kom til uttrykk i et intervju med elever ved restaurant- og matfag. Da jeg spurte om de hadde undervisning om ulike religiøse matskikker, som for eksempel halal, svarte de kort og godt følgende: «Nei, vi har ikke så mye om det for vi har ingen muslimer på trinnet». Elever trenger kunnskap om religiøse matskikker uavhengig av elevsammensetningen i klassen, og dette illustrerer tydelig negative følger av en representasjonstenking.

En annen form for framsnakking av minoritetselever kom særlig til uttrykk $i$ et intervju med lærere ved helse- og oppvekstfag. De var opptatt av at noen jenter med bakgrunn fra enkelte asiatiske land, hadde særskilte fortrinn som framtidige helsearbeidere. 
Lærer 1: Når vi snakker om det å skulle ut i praksis og det... det er jo veldig mange eldre mennesker de møter i praksis. Både på institusjon og i hjemmesykepleien. Og det er jo kanskje mye større respekt for eldre mennesker blant en del av de fremmedkulturelle enn blant de norske. Så det er også noe som kan være greit å ha opp i sånn plenumsdiskusjon i klassen. Ja.

Lærer 2: Ja, det har vi opplevd, ja.

Lærer 3: Ja, ja det har jeg opplevd.

Lærer 1: Veldig mange eldre ute [i praksis], de bare forguder jo mange av våre elever, fordi [de opplever] en enorm respekt fra disse elevene. Og et håndlag fra de som er helt....

Intervjuer: Kan det hende at de er vant med mer hjemmefra?

Lærer 1: Fra sin kultur, ja.

Intervjuer: Å faktisk også være med å stelle foreldre, eller?

Lærer 2: De har vel ikke sykehjem sånn som oss, så de tar jo hånd om familien sin hjemme. Ja. Så de syns jo det er rart at det er så mange på sykehjem.

Lærerne i denne dialogen er enige om at «de fremmedkulturelle elevene» har større respekt for eldre mennesker enn «de norske». Av den grunn er det mange eldre som forguder «de fremmedekulturelle elevene». Disse elevene har dessuten et særlig godt «håndlag» med de eldre. I denne dialogen kan jeg som intervjuer sies å delvis legge ord i munnen på lærerne. Men slik jeg forstår lærerne, ser de «de fremmedkulturelle» elevenes respekt for eldre mennesker og deres særlig gode «håndlag» med eldre, i sammenheng med elevenes «kultur». Lærerne var åpenbart begeistret for disse elevene og det de oppfattet som deres omsorgsevne, som sprang ut fra deres (fremmede) kultur og/eller religion. En kritisk analyse av denne begeistringen kan imidlertid antyde at jentene roses for en type femininitet som er kjennetegnet av omsorg og respekt, som ikke uten videre korresponderer med den typen femininitet som vanligvis knyttes til det som framstilles som «norsk kjønnslikestilling». Dersom representanter for minoritetsgrupper hadde framhevet denne typen femininitet som særlig fortjenestefull og som et ideal, ville de trolig møtt motstand og fătt beskjed om at «her i Norge» er den typen kjønnsidealer utdaterte og ikke i tråd med norske likestillingsidealer. Lærernes framstillinger antyder dermed et dilemma: Studentene som beskrives her omtales som svært attraktive helsearbeider i kraft av sin kulturelt betingede femininitet. Samtidig oppmuntres de dermed til å dyrke en form for kjønnsidealer/praksis som ikke er anerkjent som «moderne» eller i tråd med «norske» likestillingsidealer. Dersom de holder fast ved sin «fremmedkulturelle» omsorgsfemininitet blir de samtidig markert som «fremmed», «den andre», og kan ikke samtidig gjøre krav på å være «norsk» eller «ekte norsk».

Lærerne som framsnakket disse «fremmedkulturelle» jentene som attraktive helsearbeidere var kanskje de som aller mest tydelig ga uttrykk for ubehag ved à skulle snakke om utfordringer knyttet til minoritetselever, som for eksempel kommunikasjonsproblemer med både elever og deres foreldre, og som virket veldig lettet da de kunne snakke positivt om forskjeller blant elevene. De ga mange ulike eksempler på hvor positivt det var med stort mangfold blant elevene, og på at minoritetselever på ulike måter bidro positivt i undervisningen. Men hvilke følger kan det få hvis man som underviser forflytter seg hastig fra ubehag til lettelse? Det er verdt å spørre om hastverket som både disse og andre lærere hadde med å komme seg ut av ubehaget, bidro til at de ikke tok seg tid til å tenke gjennom utfordringer knyttet til de forståelsesmåtene og framstillingene som de trakk veksler på, når de fortolket og snakket om elever med minoritetsbakgrunn. Eksemplene i det foregående indikerer at det å haste bort fra ubehaget for å oppnå rask lettelse, kan føre til en forhastet 
framsnakking av minoritetselevers positive annerledeshet. Med utgangspunkt i de aller beste intensjoner kan denne typen framsnakking bidra til å reprodusere stereotypier framfor å fremme kritisk, inkluderende og antidiskriminerende undervisning.

En velkjent form for framsnakking av minoritetselever er begeistrede fortellinger om minoritetselever som lager mat fra sitt eller foreldrenes hjemland og som tar med religiøse eller kulturelle rekvisitter og viser fram i undervisningen. Denne typen «velvillig» eller «overfladisk» flerkulturell pedagogikk er, som allerede nevnt, grundig problematisert innenfor ulike varianter av kritisk pedagogikk, og anklaget for å komme til kort når det gjelder a behandle utfordringer knyttet til maktforhold og rasisme (jf. May 2009; Zembylas \& Papamichael 2017). Jeg har selv intervjuet lærere som med begeistring forteller om hvordan de eller deres skole fokuserer på mat, klær og dans når de behandler kulturelt mangfold (Røthing 2017, s. 65-72), og det er mulig de ville blitt frustrerte eller fornærmet dersom jeg i intervjusituasjonen hadde konfrontert dem med kritikk av denne typen undervisningspraksiser. Zembylas \& Papamichael (2017) forteller om et etterutdanningskurs for lærere, der noen av deltakerne på kurset reagerte kraftig på foreleserens kritikk av denne typen undervisningspraksis. De ble frustrerte og sinte over å fă beskjed om at «det vi har gjort er feil» (s. 10). Lærerne forsvarte seg med at de hadde lært at det var riktig å undervise om kulturelt mangfold på denne måten. Min erfaring er at lærere som făr tilbud om nye, kritiske perspektiver på egen undervisningspraksis, først og fremst blir entusiastiske og motiverte. Dette indikerer etter mitt syn at vi kan vinne på å stå i ubehag framfor å prøve å unngå det. Dersom vi søker raskt bort fra ubehaget kan vi gå glipp av gevinstene ved å stoppe opp og undersøke og tematisere hva som skaper ubehag. Hva som skaper ubehag for den enkelte vil selvsagt variere. Mange av oss vil likevel få god hjelp av ulike kritiske perspektiver som bidrar til bevissthet omkring maktforhold, privilegier og normer, for å forstå hvor ubehag kommer fra og hvilke relasjonelle forhold og betingelser som settes i sving når ubehag oppstår.

\section{Upassende ubehag?}

Ubehaget i de bråkete og kaotiske timene som jeg beskrev innledningsvis, gjorde inntrykk på meg. Det samme gjorde lettelsen som jeg opplevde da jeg kom til den andre skolen, der det var rolige og harmoniske forhold i klasserommet. En morgen på den andre skolen, da en elev rakk opp hånda og fortalte at han dessverre - av plausible grunner - ikke hadde fătt anledning til å gjøre leksene de skulle gå gjennom, men at han ville sørge for å få gjort dem til påfølgende dag, begynte jeg nesten å gråte. Både av lettelse, men ikke minst av tristhet ved tanken på elever og lærere ved den første skolen, som daglig skulle lære og arbeide under så helt andre betingelser. Forskjellene som jeg opplevde mellom de to skolene, kan forstås i lys av relasjonene mellom elever og lærere. På den andre skolen så det ut som om elever og lærere var på parti med hverandre. De framsto som allierte. Det var i langt mindre grad tilfellet på den første skolen. Selvsagt var det variasjon, men det overgripende inntrykket var at elever og lærere ikke var allierte. Disse opplevelsene av ubehag, lettelse og forskjeller mellom skolene, er det imidlertid ikke helt enkelt å sette ord på. Både ubehaget og lettelsen føles upassende. Det føles ugreit å beskrive tydelige forskjeller i klasseromsdynamikk mellom de to skolene, fordi beskrivelsene så lett kan konverteres til forklaringer av typen: På den første skolen er det bråkete og kaotisk fordi det er stor andel elever med minoritetsbakgrunn der, på den andre skolen er det rolig og harmonisk fordi det er en stor andel elever med majoritetsbakgrunn der. Umiddelbart, etter å ha formulert denne typen enkle forklaringer, vet man at de ikke holder vann. Det er alltid mer komplekst enn som så. Sosial bakgrunn $i$ samspill med etnisitet, vil gi et langt bedre inntak til å forstå forskjellene mellom skolene enn et ensidig fokus på etnisitet. Sannsynligvis vil sosial bakgrunn som enkeltfaktor gi en bedre inngang til å forstå forskjellene enn etnisitet som enkeltfaktor. Det er imidlertid verdt å ta på alvor at det er knyttet ubehag til å skrive om denne typen forskjeller. For hva kan vi gå glipp av, av økt kunnskap og forståelse, dersom det ikke føles legitimt å peke på forskjeller eller 
konkrete forhold, av frykt for at de kan komme til å knyttes til etnisitet på stigmatiserende måter?

Kjersti Thorbjørnsrud gir i en kronikk i Morgenbladet (19.10.18) uttrykk for et ubehag som ser ut til à springe ut fra lignende dilemmaer og uro som mitt eget ubehag knyttet til å snakke om forskjeller mellom de to nevnte skolene. Thorbjørnsrud refererer en informant med majoritetsbakgrunn som er bekymret for datterens sosiale miljø. Informanten bor $\mathrm{i}$ en bydel der de etnisk norske barna er i minoritet, og hun fortalte om etnisk norske barn som ble mobbet på skolen og om «et fellesskap basert på religiøs tilhørighet, der det å ikke være muslim lett gjorde at man ble definert som 'den andre'.» I epost til forskeren spør informanten: «Vi opplever strammere sosial kontroll; i klassen er nesten alle med minoritetsbakgrunn muslimer. Følger forskerne med på denne utviklingen?». Thorbjørnsrud beskriver sitt eget ubehag knyttet til å skulle forfølge den typen spørsmål som informanten stilte. Hun var urolig for à skulle bli misforstått og kjente på en «frykt for klamme omfavnelser fra bevegelser forskere helst ikke bør bli identifisert med», eller for å møte taushet fra forskerkollegaer (se også Borchgrevink 2002).

I boka Kampen om vitenskapeligheten (2018) drøfter også Mette Andersson blant annet denne typen uro knyttet til migrasjonsforskeres erfaringer med formidling og kommunikasjon i offentligheten, innen et politisk betent felt. Forskere som befatter seg med innvandring blir, skriver hun, ofte kritisert for à være «normative, politisk korrekte eller passive tjenere for staten eller bestemte interessegrupper». Dessuten blir de «også beskyldt for å unngå å ta opp vanskelig saker i samfunnsdebatten» og «deres motiver og metoder kan bli latterliggjort» (s. 15). Andersson beskriver et fagfelt som utsettes for kritikk fra høyreekstreme grupper som kan oppleves skremmende, og som samtidig «har vært preget av harde kamper og streng intern justis» (Thorbjørnsrud 2018) med hensyn til hva som regnes som anstendig forskning. På tross av at det kan være utfordrende å finne «respektable posisjoner» (Borchgrevink 2002, s. 149) i dette landskapet, og på tross av et polarisert debattklima som det Thorbjørnsrud og Andersson beskriver (se også Kolshus 2018), vil jeg argumentere for at det er viktig å forfølge også ubehag som ikke uten videre kan forstås og fortolkes i tråd med perspektiver som først og fremst fokuserer på marginalisering av minoriteter.

En sentral diskusjon knyttet til forskning innen politisk betente områder, er ikke bare valg av teoretiske perspektiver, men også valg av empiriske eksempler. Thorbjørnsrud drøfter dette i sin kronikk og peker på at selv om utfordringer som «den majoritetsnorske minoriteten» kan oppleve i deler av Oslo, i noe større grad har blitt tematisert i nyere forskningsrapporter sammenlignet med tidligere, så får disse problemstillingene påfallende lite oppmerksomhet også i de nye rapportenes konklusjoner. Dette kan handle om valg og vektlegging som vi alle gjør som forskere. Men det er likevel verdt å spørre om noen problemstillinger fortere enn andre velges bort fordi det, som antydet over, oppleves som ubehagelig og utrygt å forfølge dem og fordi de ikke uten videre kan belyses ved hjelp av perspektiver som avdekker minoriteters utsatthet. I lys av dette er det all grunn til å også se nærmere på mine egne valg og vektlegginger. I fortsettelsen vil jeg kort drøfte to eksempler.

I et intervju med programfagslærere innen helse- og oppvekstfag, knyttet til prosjektet mangfold i yrkesfag, kom det fram at lærerne ergret seg over elever med minoritetsbakgrunn som «blikket» og irettesatte andre minoritetselever, som ikke praktiserte islam på samme teologisk konservative måte som dem selv. Dette skapte til dels store konflikter blant elevene og vanskelige arbeidsforhold i klassen, og lærerne var både irriterte, frustrerte og rådville. Samtidig var det tydelig forbundet med ubehag å snakke om dette. Lærerne hadde i større grad et språk for å snakke om minoritetselevers erfaringer med rasisme eller sosial kontroll fra familien. De hadde i mindre grad et språk for å snakke om konflikter mellom elever med minoritetsbakgrunn og ikke minst om minoritetselever som drev religiøst begrunnet trakassering og plaging av medelever. I boka Mangfoldskompetanse $i$ yrkesfag (2017) nevner jeg denne tematikken (s. 79-80). Men det er grunn til å spørre hvorfor jeg ikke løftet den fram mer. Hvorfor var ikke dette en tematikk jeg forfulgte og prøvde å forstå og belyse bedre? 
I lys av Thorbjørnsrud og Anderssons refleksjoner som er gjengitt over, er det nærliggende à anta at det var forbundet med ubehag å skulle skrive om maktforhold på måter som ikke først og fremst tegner et bilde av minoriteter som utsatte og marginaliserte. Dessuten, med utgangspunkt i den typen maktkritiske perspektiver som jeg var vant med å anvende, falt denne tematikken utenfor. Eller mer brutalt: Det passet ikke inn. Lærere som ønsker innspill til hvordan de kan stå i denne typen ubehag og best handle i denne typen situasjoner, fant med andre ord ikke særlig hjelp i det jeg skrev.

Det andre eksemplet jeg vil nevne er hentet fra studien om norskhet i skolen, basert på klasseromsobservasjoner og intervjuer med lærere. I fire av de åtte intervjuene med lærere fra skolen der det var utmattende og ubehagelig å gjøre observasjoner, kom det fram at minoritetselever ved skolen ikke sjelden anklaget lærere for å være rasister. Det varierte i hvilken grad lærerne som fortalte om dette, selv var anklaget og hvor alvorlig de tok det, men det var tydeligvis en tematikk som opptok flere av lærerne ved skolen. En av dem fortalte om det han opplevde som en forskjell mellom minoritets- og majoritetselevene, nemlig at de førstnevnte reagerer «mye mer aggressivt» på negativ respons. I forlengelsen av dette fortalte han at «elevene sier til meg at den og den læreren er rasist, fordi de føler ofte at forskjellsbehandlingen går på hudfarge eller kulturell bakgrunn». En annen fortalte at hun selv hadde blitt anklaget for å være rasist da hun for eksempel hadde «snakket til elever, bedt dem om å være stille, eller sendt dem på gangen, eller sagt at nå får du en anmerkning.» En tredje lærer fortalte at minoritetselever reagerte på å bli tatt ut av fellesundervisningen for å få såkalt styrket undervisning, basert på lærernes faglige vurdering. Elevene opplevde det som stigmatiserende og som en type forskjellsbehandling: «Jeg har tatt ut en gruppe i styrking og de har vært veldig sånn at 'dette er rasistisk, det er bare fordi vi er mørkhudede'».

Jeg merket meg denne tematikken da jeg jobbet med dette forskningsprosjektet i perioden 2008-2010, men jeg fant ikke noen anledning til å skrive om det. Kanskje spurte jeg meg selv om det ville være legitimt å skrive om læreres ubehag og frustrasjon knyttet til å bli kalt rasister. Var det ikke viktigere å sette søkelys på hvordan lærere eventuelt bidro til andregjøring og marginalisering av etniske minoritetselever? Og kanskje var det sant at minoritetselevene ble diskriminert? De siste årene har rapporter og studier pekt på at norske minoritetsungdommer opplever diskriminering og rasisme, også i skolekonteksten (Se f.eks. Trøften 2010; Antirasistisk senter 2017; Chinga-Ramirez 2018). Dette er viktig kunnskap som skal tas på største alvor. Men det er verdt å stille følgende spørsmål: Er det en motsetning mellom å ta unges opplevelser av rasisme på alvor og samtidig anerkjenne læreres ubehag og frustrasjon over å bli anklaget for à være rasister?

Lærerne som ble anklaget for å være rasister, ga uttrykk for at de syntes det var både urettferdig, frustrerende og ubehagelig. Det er vanskelig ̊̊ forsvare seg mot den typen anklager og mot elevenes opplevelser og oppfatninger. Det kan selvsagt være lærere som anklages med rette. Men jeg legger til grunn at lærere flest ønsker å behandle elevene sine rettferdig. I det første sitatet over ble det sagt at minoritetselever møter negativ tilbakemelding fra lærere mer aggressivt enn majoritetselever. Dette koples sammen med elevenes anklager om at lærerne er rasister. Her framtrer med andre ord et bilde av elever som føler seg forskjellsbehandlet og dårlig behandlet, og som ikke usannsynlig opplever seg som utsatt og marginalisert. Dette vil tre fram umiddelbart hvis man anvender normkritiske og antirasistiske perspektiver. Det er imidlertid rimelig å hevde at minoritetselevene også disponerer en form for makt i relasjonen mellom dem og lærerne. De er sannsynligvis klar over at det er vanskelig for lærere som anklages for å være rasister, å forsvare seg. Lærernes handlingsrom innskrenkes og avstanden mellom elever og lærere øker og sementeres. I en slik situasjon blir det vanskelig for lærerne å utøve sitt arbeid i tråd med pedagogiske og relasjonelle idealer, og elevenes læringsmiljø forringes. Det er et maktspill på gang her og lærere og elever er åpenbart ikke på lag, de er ikke allierte. Noen vil kanskje mene at det er viktigere å sette søkelys på elevers erfaringer med rasisme og marginalisering i skolen, og at læreres ubehag og frustrasjon knyttet til å bli anklaget for å være rasist ikke er en like verdig 
tematikk å forfølge. Jeg tror imidlertid at denne typen maktspill forstås best hvis man forsøker à ta begge parters perspektiver på alvor. Dessuten tror jeg at lærernes ubehag og opplevelser kan gi viktige innganger til å forstå samspill og maktforhold mellom elever og lærere, og kanskje også noen tips til alliansebygging og lagspill.

\section{Hvem sitt ubehag?}

I denne artikkelen har jeg argumentert for at ubehag kan være et inntak til refleksjon omkring, og økt innsikt i, egne forståelsesmåter, og at vi derfor kan utvikle bedre grunnlag for kritisk og inkluderende undervisning ved å stå i ubehaget framfor å søke oss raskt bort fra det. Mitt hovedfokus har vært på hvordan ubehag kan forstås som en ressurs for oss som undervisere. Det opprinnelige utgangspunktet for ubehagets pedagogikk var imidlertid et ønske om å engasjere ikke bare lærere, men også studenter og elever, til å behandle temaer knyttet til forskjeller, sosial rettferdighet og rasisme på måter som utfordret deres emosjonelle komfortsoner. Denne ambisjonen peker imidlertid i retning av noen etiske dilemmaer: Er det riktig av lærere å aktivt skape eller framprovosere ubehag hos elever for à fremme læring? Hvilke etiske forpliktelser er forbundet med hvem sitt ubehag som oppmuntres i forbindelse med ubehagets pedagogikk? Et annet relevant spørsmål er om ubehag nødvendigvis skaper læring? Eller sagt på en annen måte; hva slags læring skaper ubehag? Hva om elever som kjenner ubehag, først og fremst blir sinte eller redde? Hva om de synes at læreren er en idiot og stenger av for utforsking av nye perspektiver framfor å åpne opp? Hvilke elever vil eventuelt kunne ha nytte av ubehag som en inngang til læring, og hvilke elever vil motsette seg ubehaget? Kan det bli slik at «ubehag» blir en ressurs som de allerede ressurssterke og privilegerte elevene kan lære å mestre, mens andre grupper av elever kan få befestet sin opplevelse av å ikke lykkes og av å ikke mestre skolen?

Det kan være gode grunner til å være skeptisk til å aktivt skulle skape ubehag hos elever, selv om det skulle være pedagogisk begrunnet. Innen antidiskriminerende og antirasistisk undervisning ligger det imidlertid et krav om å utfordre forståelsesmåter som reproduserer maktforhold og privilegier, og dette kan oppleves som utfordrende og ubehagelig for elever. Det er imidlertid nødvendig å huske på at elever er ulike og er posisjonert forskjellig i klasserommet og samfunnet. Derfor vil det i like stor grad kunne oppleves som utfordrende og ubehagelig for enkelte grupper av elever dersom lærere ikke utfordre denne typen forståelsesmåter. Spørsmålet om trygge og behagelig klasserom, og om det er forsvarlig å skape ubehag hos elever, er med andre ord komplekst, og dette gjelder nettopp særlig temaer knyttet til forskjeller, sosial rettferdighet og rasisme. Tilnærminger som er behagelige for noen elever kan være ubehagelige for andre, og spørsmål som utfordrer noen elevers komfortsone kan gi andre elever håp om å bli sett og ivaretatt. Spørsmålet om trygge eller ubehagelige klasserom er med andre ord mer presist et spørsmål om trygge eller ubehagelige klasserom for hvem. Dette peker i retning av at det ikke først og fremst blir et spørsmål om hvorvidt lærere skal fremkalle ubehag eller ikke hos elever, men snarere om hvordan behag og ubehag skal fordeles mellom ulike elever og om hvordan lærere kan forvalte elevers trygghet og ubehag. I et aktivt arbeid med ubehag som ressurs, både for undervisere, studenter og elever, er det følgelig viktig å samtidig utvikle beredskap for å møte og ivareta elever og studenters ubehag, både når det er framkalt og forventet og når det oppstår uventet i daglig samspill. Med utgangspunkt i maktkritiske perspektiver vil ubehag nødvendigvis forstås i lys av maktforhold. For å kunne utvikle best mulig forståelse av situasjoner som skaper ubehag, er det imidlertid nødvendig å ikke legge til grunn at makt alltid opptrer på gitte måter.

I siste del av artikkelen har jeg argumentert for at ubehag som ikke uten videre kan forstås og behandles innenfor rammene av tradisjonell maktkritisk pedagogikk, også bør utforskes i arbeidet med å utvikle og fremme kritisk refleksjon og inkludering i utdanningsfeltet. Det er minst to grunner til dette. Det ene handler om empirisk redelighet. Det upassende ubehaget finnes i norske skoler og utdanningsinstitusjoner, og det gagner ingen à late som noe annet. 
Det andre handler om relevant kunnskapsutvikling. I en fersk artikkel om antropologiens bidrag i norsk offentlighet bemerker Thorgeir Kolshus (2018) at antropologien i dag, til forskjell fra på 1980- og 90-tallet, ikke lenger tilbyr kunnskap om de konkrete utfordringer som praktikere står overfor, og derfor søker de til andre: «Vi oppleves rett og slett ikke som relevante lenger, for vi stiller ikke de spørsmålene de trenger svar på» (2018, s. 46). Dette kan leses som både en påminnelse og advarsel til alle som ønsker å utvikle forskningsbasert kunnskap med relevans for praktikere, inkludert profesjonsutøvere i utdanningsfeltet. Vi som er opptatt av maktforhold og arbeid med kritisk refleksjon og inkludering i skoler og høyere utdanning, må være lydhøre for hvilke spørsmål undervisere stiller og hvilke utfordringer de og vi erfarer. Ubehag kan være en inngang til dette arbeidet, gjennom utforsking av hvor det kommer fra og hva det gjør. Og når ubehaget ikke uten videre kan forstås ved hjelp av de perspektivene vi forventer eller ønsker, er det verdt å stoppe opp og se etter nye innganger til relevant kunnskapsutvikling. 


\section{Referanser}

Andersson, Mette (2018). Kampen om vitenskapeligheten. Forskningskommunikasjon i et politisk betent felt. Oslo: Universitetsforlaget.

https://doi.org/10.18261/9788215030036-2018-01

Anker, Trine og von der Lippe, Marie (2015). Når terror ties i hjel - En diskusjon om 22. juli og demokratisk medborgerskap i skolen. Norsk Pedagogisk tidsskrift, 99 (2), s. 85-96.

Anker, Trine og von der Lippe, Marie (2016). Tid for terror. Læreres håndtering av kontroversielle spørsmål i skolens religions- og livssynsundervisning. Prismet. Oslo: IKO-forlaget, s. 261-272.

Antirasistisk senter (2017). «Vi vil ikke leke med deg fordi du er brun» - en undersøkelse av opplevd rasisme blant ungdom. Oslo.

Biesta, Gert J. J. (2014). Utdanningens vidunderlige risiko. Berge: Fagbokforlaget.

Boler, Megan (1999). Feeling power: Emotions and education. New York: Routledge.

Boler, Megan og Zembylas, Michalinos (2003). Discomforting truths: The emotional terrain of understanding differences. I: P. Tryfonas (red.), Pedagogies of difference: Rethinking education for social justice (s. 117-131). New York: Routledge Falmer.

Borchgrevink, Tordis (2002). Likestilling. Det flerkulturelle demokratiets hodepine. I:

Brochmann, Grete, Borchgrevink, Tordis \& Rogstad, Jon, Sand i maskineriet. Makt og demokrati i det flerkulturelle Norge (s. 146-173). Oslo: Gyldendal akademisk.

Bromseth, Janne C. H. og Darj, Frida (red.). (2010). Normkritisk pedagogik : makt, lärande och strategier för förändring. Uppsala: Centrum för genusvetenskap, Uppsala University.

Chinga-Ramirez, Carla (2018). Om å være farget - Betydning av hudfarge for hungdom med vestlig minoritetsbakgrunn. I: Øksnes, Maria, Sundsdal, Einar og Haugen, Cecilie R. (red.)

Ungdom, danning og fellesskap. Samfunns-og kulturpedagogiske perspektiv. Oslo: Cappelen Damm Akademisk.

Clough, Patricia T. (2007). Introduction. I: Clough, Patricia T. og Halley, Jean (red.) The affective turn: Theorizing in the social (s. 1-33). Durham, NC: Duke University Press.

Cutri, Ramona Maile og Whiting, Erin Feinauer (2015) The emotional work of discomfort and vulnerability in multicultural teacher education, Teachers and Teaching, 21:8,1010-1025, https://doi.org/10.1080/13540602.2015.1005869

De Freitas, Elizabeth og McAuley, Alexander (2008). Teaching for diversity by troubling whiteness: strategies for classrooms in isolated white communities. Race, Ethnicity and Education, 11 (4) 429-442 https://doi.org/10.1080/13613320802479018

Eriksen, Ingunn M. (2013). Young Norwegians. Belonging and becoming in a multiethnic high school. Dissertation for the degree of PhD. University of Oslo, Faculty of Humanities.

Gressgård, R. \& Harlap, Y. (2014). Spenninger i klasserommet: Mikroaggresjon som pedagogisk utfordring. Uniped, 37 (3), 23-33. https://doi.org/10.3402/uniped.v37.23779

Iversen, Lars L. (2012). Learning to be a Norwegian: A case study of identity management in religious education in Norway. Münster: Waxmann.

Kalonaityte, Viktorija. (2014). Normkritisk pedagogik - för den högre utbildningen Lund:Studentlitteratur.

Kolshus, Thorgeir (2018). Fra grobunn til stengrunn. Kulturrelativismens skjebne i norsk offentlighet. Norsk Antropologisk Tidsskrift, 29 (1-2), $42-57$. https://doi.org/10.18261/issn.1504-2898-2018-01-02-04 
Kumashiro, Kevin (2002). Troubling Education: Queer activism and antioppressive education. New York: Routledge.

Lalvani, Priya og Broderick, Alicia A. (2013). Institutionalized Ableism and the Misguided "Disability Awareness Day": Transformative Pedagogies for Teacher Education. Equity \& Excellence in Education 46(4), 468-483 (15 s)

Martinsson, Lena, Reimers, Eva, Reingarde, Jolanta og Lundgren, Anna Sofia (2007). Norms at work: Challenging homophobia and heteronormativity. Stockholm: RFSL.

Martinsson, Lena og Reimers, Eva (red.) (2008). Skola i normer. Malmö: Gleerup.

May, Stephen (2009). Critical multiculturalism and education. I: Banks, James A. (red). The Routledge International Companion to Multicultural Education (s. 33-48). New York: Routledge.

Mühleisen, Wencke, Røthing, Åse og Svendsen, Stine H., (2009). Norske seksualiteter - en innledning. I: Mühleisen, Wencke og Røthing, Åse (red.): Norske seksualiteter. Oslo: Cappelen akademisk forlag.

Often, Anne (2018). Norske jøder som nasjonal minoritet i historieundervisning - En studie basert på intervjuer med lærere på videregående skole. MA-oppgave, OsloMet Storbyuniversitetet, Oslo.

Røthing, Åse (2007). Homonegativisme og homofobi i klasserommet. Marginaliserte maskuliniteter, disiplinerende jenter og rådville lærere. Tidsskrift for ungdomsforskning, 7, 27-51.

Røthing, Åse (2011). 'De norske har det mer i seg ...' Norsk kjønnslikestilling i skolen. Sosiologi i dag. 41(3/4), 67-87.

Røthing, Åse (2016). Normkritiske perspektiver og mangfoldskompetanse. Bedre skole nr. 3: 33-37. Oslo: Utdanningsforbundet.

Røthing, Åse (2017). Mangfoldskompetanse. Perspektiver på undervisning i yrkesfag. Oslo: Cappelen Damm akademisk.

Røthing, Åse og Svendsen, Stine H. Bang Svendsen (2009). Seksualitet $i$ skolen. Perspektiver på undervisning. Oslo: Cappelen Damm Akademisk.

Skinstad van der Kooij, Kristin (2014). Flerkulturell pedagogikk. I: Stray, Janicke Heldal og Wittek, Line (red.): Pedagogikk - en grunnbok (s. 584-598). Oslo: Cappelen Damm Akademisk.

Sue, Derald Wing (red.) (2010). Microaggressions and Marginality. Manifestation, Dynamics, and Impact. New Jersey: John Wiley \& Sons.

Svendsen, Stine H. Bang (2014). Learning racism in the absence of 'race'. European Journal of Women's Studies, 21, 9-24. https://doi.org/10.1177/1350506813507717

Thomas, Paul (2016). Exploring Anti-Semitism in the Classroom: A Case Study Among Norwegian Adolescents from Minority Backgrounds, Journal of Jewish Education, 82(3), 182-207.

Thorbjørnsrud, Kjersti (2018, 19. oktober). Forskernes nyanser ender med å dempe det som er vondt, Morgenbladet. Hentet fra https://morgenbladet.no/ideer/2018/10/samfunnsforskere-er-ikke-interessert-i-dennorske-minoritetens-erfaringer-skriver

Trøften, Dorte (2010). Skolen er fra Mars, elevene er fra Venus - utdanning i et multietnisk samfunn. Oslo: Organisasjonen mot offentlig diskriminering (OMOD).

Zembylas, Michalinos (2010). Teachers' emotional experiences of growing diversity and multiculturalism in schools and the prospects of an ethic of discomfort, Teachers and Teaching: theory and practice, 16(6), 703-716. https://doi.org/10.1080/13540602.2010.517687 
Zembylas, Michalinos (2014). Theorizing "Difficult Knowledge" in the Aftermath of the "Affective Turn": Implications for Curriculum and Pedagogy in Handling Traumatic Representations, Curriculum Inquiry, 44(3), 390-412.

Zembylas, Michalinos (2015). "Pedagogy of discomfort" and its ethical implications: the tensions of ethical violence in social justice education, Ethics and Education, 10(2), 163-174.

Zembylas, Michalinos og Papamichael, Elena (2017) Pedagogies of discomfort and empathy in multicultural teacher education, Intercultural Education, 28:1, 1-19. 